\title{
A new genus of mongoliulid millipedes from the Far East of Russia, with a list of species in the family (Diplopoda, Julida, Mongoliulidae)
}

\author{
Henrik ENGHOFF ${ }^{1, *}$, Laura Mark JENSEN ${ }^{2}$ \& Elena V. MIKHALJOVA ${ }^{3}$ \\ ${ }^{1,2}$ Natural History Museum of Denmark (Zoological Museum), University of Copenhagen, \\ Universitetsparken 15, DK-2100 Copenhagen Ø, Denmark. \\ ${ }^{3}$ Federal Scientific Center of the East Asia Terrestrial Biodiversity, Far Eastern Branch \\ of the Russian Academy of Sciences, Vladivostok 690022, Russia. \\ "Corresponding author: henghoff@snm.ku.dk \\ ${ }^{2}$ Email: 1je@science.ku.dk \\ ${ }^{3}$ Email: mikhaljova@biosoil.ru \\ ${ }^{1}$ urn:Isid:zoobank.org:author:FB09A817-000D-43C3-BCC4-2BC1E5373635 \\ ${ }^{2}$ urn:lsid:zoobank.org:author:94D005CA-3A86-4FEE-BA71-A92F29915DDA \\ ${ }^{3}$ urn:1sid:zoobank.org:author:C7962B1F-80FD-4330-AF41-C17B7EA0214C
}

\begin{abstract}
The genus Koiulus gen. nov. and its type-species, Koiulus interruptus gen. et sp. nov., are described from the Russian Far East. The new genus is compared with other genera of Mongoliulidae, in particular with Ussuriiulus Golovatch, 1980, also from the Russian Far East, with which it shares the absence of ozopores from individual body rings distributed along the body, a condition so far otherwise unknown in the superorder Juliformia. A synoptic table of genera and a list of species of Mongoliulidae are presented.
\end{abstract}

Keywords. Taxonomy, new species.

Enghoff H., Jensen L.M. \& Mikhaljova E.V. 2017. A new genus of mongoliulid millipedes from the Far East of Russia, with a list of species in the family (Diplopoda, Julida, Mongoliulidae). European Journal of Taxonomy 326: 1-19. https://doi.org/10.5852/ejt.2017.326

\section{Introduction}

The Mongoliulidae is a small family of small to medium-sized julidan millipedes, geographically confined to East Asia (Russian Far East, Korea, China, Japan). Up to now, seven genera of the family have been described: Ansiulus Takakuwa, 1940a (Korea, Russian Far East, 4 species), Ikahoiulus Takakuwa, 1941 (Japan, monotypic), Kopidoiulus Attems, 1909 (Japan, Russian Far East, 7 species), Senbutudoiulus Miyosi, 1957 (Japan, monotypic), Skleroprotopus Attems, 1901 (= syn. Mongoliulus Pocock, 1903) (Japan, Korea, China, Russian Far East, 20 species), Uenoiulus Murakami, 1971 (Japan, monotypic), and Ussuriiulus Golovatch, 1980 (Russian Far East, monotypic). The family includes cave dwellers as well as surface living species. 
Considering the small size of the family, the morphological diversity regarding secondary sexual characters, especially in males, is considerable, and the new genus described here adds significantly to this diversity. Of special interest is that the type and only species of the new genus, instead of having a continuous series of defense gland openings (ozopores) starting on body ring 6 as in virtually all other juliformian millipedes (in some the series starts on ring 5, though, exceptionally on ring 3 ), has the series interrupted by ozopore-less rings at more or less regular intervals. This trait, which was also reported from Ussuriiulus by Golovatch (1980), but has otherwise been neglected, adds particular interest to the new genus and its type species. This will be discussed in a separate paper.

\title{
Material and methods
}

The material treated here has been deposited in the collections of the Zoological Museum, University of Copenhagen, Denmark (ZMUC), Federal Scientific Center of the East Asia Terrestrial Biodiversity, Far Eastern Branch of the Russian Academy of Sciences, Vladivostok, Russia (FSCB) and the Zoological Museum of the State University of Moscow, Russia (ZMUM). Paratypes of Uenoiulus notabilis Murakami, 1971 were borrowed from the National Museum of Nature and Science, Ibaraki, Japan (NMNS). The material was preserved in $70-75 \%$ alcohol and examined in alcohol under a stereo microscope. Gonopods and some other parts were dissected from a limited number of males and females and mounted in Canada balsam or temporarily in glycerine.

The numbers of podous and apodous rings were counted, and body length and midbody vertical diameter were measured on all entire specimens. For females, only maximum values are given because of difficulties in distinguishing juvenile and adult females without dissection.

Specimens for scanning electron microscopy (SEM) were transferred to $96 \%$ ethanol, then to acetone, air-dried, mounted on aluminium stubs or on pieces of flexible aluminium tape and in turn mounted on stubs, coated with platinum-palladium and studied in a JEOL JSM-6335F scanning electron microscope. SEM images were processed in PhotoShop and plates were composed in Microsoft Publisher.

\section{Results}

Class Diplopoda de Blainville in Gervais, 1844

Order Julida Brandt, 1833

Family Mongoliulidae Pocock, 1903

\author{
Koiulus gen. nov. \\ urn:1sid:zoobank.org:act:D052E0D9-ACCC-4F3C-8726-318012B92450
}

\section{Diagnosis}

A genus of Mongoliulidae characterized by lacking ozopores on certain body rings (shared with Ussuriiulus), strongly reduced, three-segmented second male legs, strongly reduced seventh male legs (shared with all other genera except Ussuriiulus), strongly reduced flagella of anterior gonopods, posterior gonopods deeply split into two equally long processes: a slender anterior and a broad posterior one.

\section{Etymology}

The specific epithet refers to the River Ko where the type locality is situated.

\section{Type and only known species}

Koiulus interruptus gen. et sp. nov. 


\section{Koiulus interruptus gen. et sp. nov. urn:1sid:zoobank.org:act:04617A80-8F8D-47E0-A237-F1A5030EBAA8}

Figs 1-9

\section{Etymology}

The species is named after the interrupted series of ozopores.

\section{Material examined}

\section{Holotype}

RUSSIA: $\partial^{\lambda}$, Khabarovskii Krai (southern), Sikhote-Alin (Central) range, upper course of river Ko, $47.074^{\circ} \mathrm{N}, 136.478^{\circ} \mathrm{E}, 700-800 \mathrm{~m}$, fir-birch forest, 23-25 May 2015, wet leaf litter, A. Hansen, M. Justesen and A. Solodovnikov leg., sample RUS 15-7a (ZMUC 00040235).

\section{Paratypes}

RUSSIA: 4 $\widehat{\partial}$ (incl. 2 used for SEM), 18 $q$ (incl. 1 used for SEM), 8 juv. $\widehat{\partial} \widehat{\partial}, 1$ juv. unsex., same data

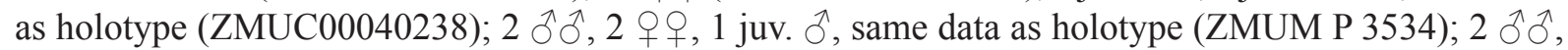
3 우, same data as holotype, but $47.037^{\circ} \mathrm{N}, 136.396^{\circ} \mathrm{E}, 580 \mathrm{~m}$, mixed forest, 22 May 2015, leaf litter and river bank and flood debris, samples RUS 15-6a and RUS 15-6b (ZMUC00040239, ZMUC00040240); $2 \widehat{\partial} \widehat{\partial}, 4$ 우, 2 juv. $\widehat{\partial} \partial^{\lambda}, 2$ juv. 웅, same data as holotype, but $47.0716^{\circ} \mathrm{N}, 136.4572^{\circ} \mathrm{E}, 750 \mathrm{~m}$, firbirch forest, 26 May 2015, leaf litter, samples RUS 15-8a and RUS 15-8e (ZMUC00040241, ZMUC 00040242); 3 ô $\widehat{\partial}, 2$ 우, same data as holotype, but $47.04^{\circ} \mathrm{N}, 136.37^{\circ} \mathrm{E}, 400-500 \mathrm{~m}$, mixed forest along the road, sample RUS 15-9 (ZMUC00040243); $1 \hat{\sigma}$ (6 trunk fragments + slightly broken head + leg pairs 1, 2 and 7, gnathochilarium and gonopods in Canada balsam), Khabarovskii Krai, ca $75 \mathrm{~km} \mathrm{SE}$ of Khabarovsk, environs of Zolotoi village, mixed forest, 5 Oct. 1981, G.N. Ganin leg. (FSCB).

\section{Description}

Measurements. See Fig. 2 for a graphical representation of size parameters. Males: length (14)19$20 \mathrm{~mm}$ (all males from river Ko site 19-20 mm), diameter $0.94-1.01 \mathrm{~mm}, 38-44$ podous rings $+2-5$ apodous rings in front of telson (fewer apodous rings in larger males). Females: length up to $21 \mathrm{~mm}$,

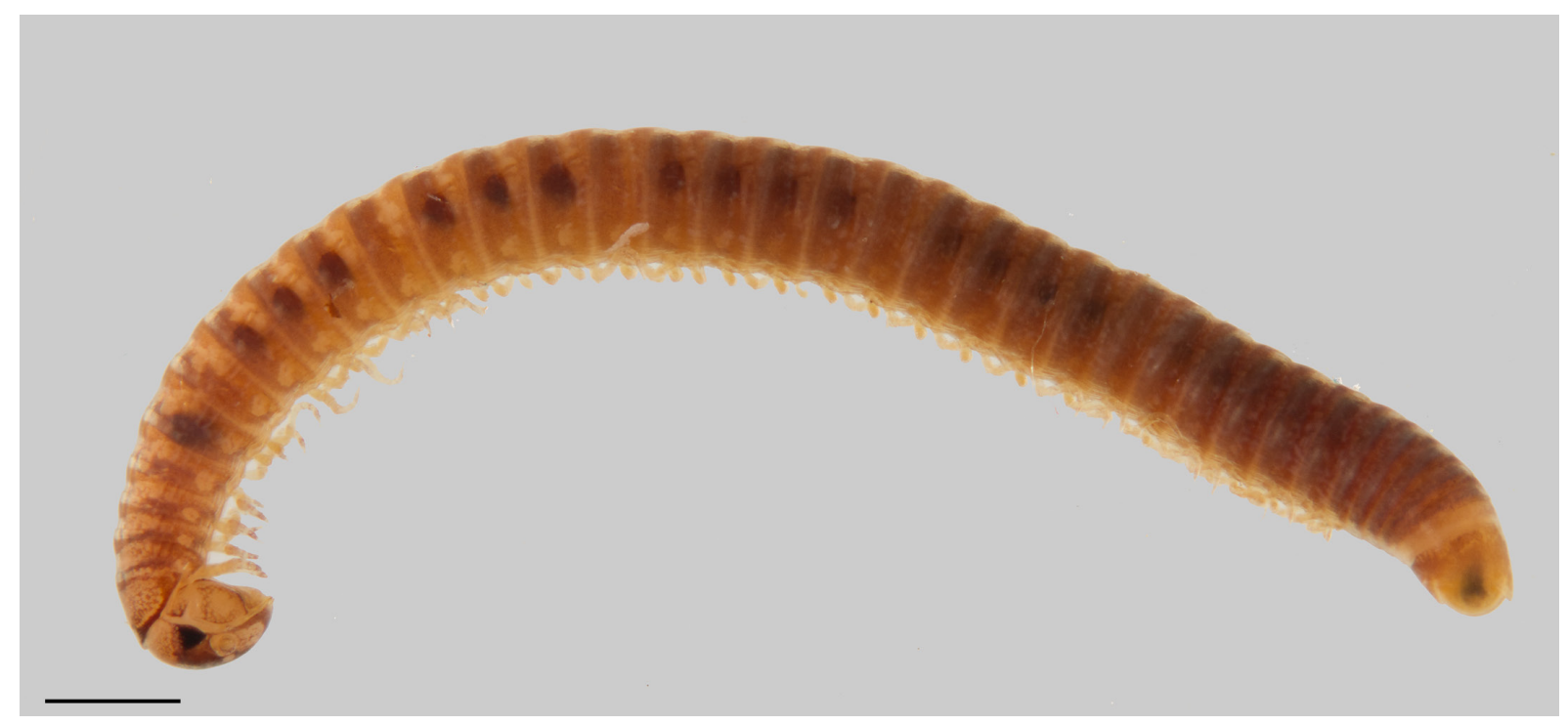

Fig. 1. Koiulus interruptus gen. et sp. nov., paratype, juvenile male from upper course of river Ko. Notice interrupted series of defense glands. Scale bar: $1 \mathrm{~mm}$. 
diameter up to $1.31 \mathrm{~mm}$, up to 46 podous rings + at least one, usually 2-5 apodous rings in front of telson (fewer apodous rings in larger females).

Colour (Fig. 1). Marbled brownish, darker dorsally, no pronounced colour pattern. Defense glands visible as dark spots on the body rings on which they occur (see below). Male from environs of Zolotoi village beige (probably faded by preservation). Eye patches black. Antennae brown.

Eye PATChes. Subtriangular, composed of 30-45 ocelli. A pair of long frontal (epicranial) setae (broken in many specimens), at least some individuals with scattered additional long setae between antennal sockets and labrum. $2+2$ supralabral setae, at least $5+5$ labral setae.

ANTENNAE. Reaching body ring 3 when folded back. Antennomeres 5, 6 and 7 each with an external subapical group and corolla of sensory bacilli; sensory bacilli of antennomere 7 minute. Antennomere 3 longer than the others: $3>2 \approx 4 \approx 5>6>>7>1$.

Mandibles (Fig. 3A-C). External tooth (odontomere of Hoffman \& Howell 1995), with three cusps decreasing in size from posterior to anterior. Internal tooth (dentate lamella of Hoffman \& Howell 1983, sectile edge of psectromere of Hoffman \& Howell 1996), with ca 5 cusps decreasing in size from posterior to anterior. Eight rows of simple pectinate teeth. Molar plate without grooves, with a row of hand-like processes, each with 3-5 bent 'fingers', along anterior margin.

Gnathochilarium (Fig. 3D-E). Three apical setae on each stipes and four or five setae in a longitudinal row on each lamella lingualis; promentum (modified in male, see below) completely separating lamellae linguales.

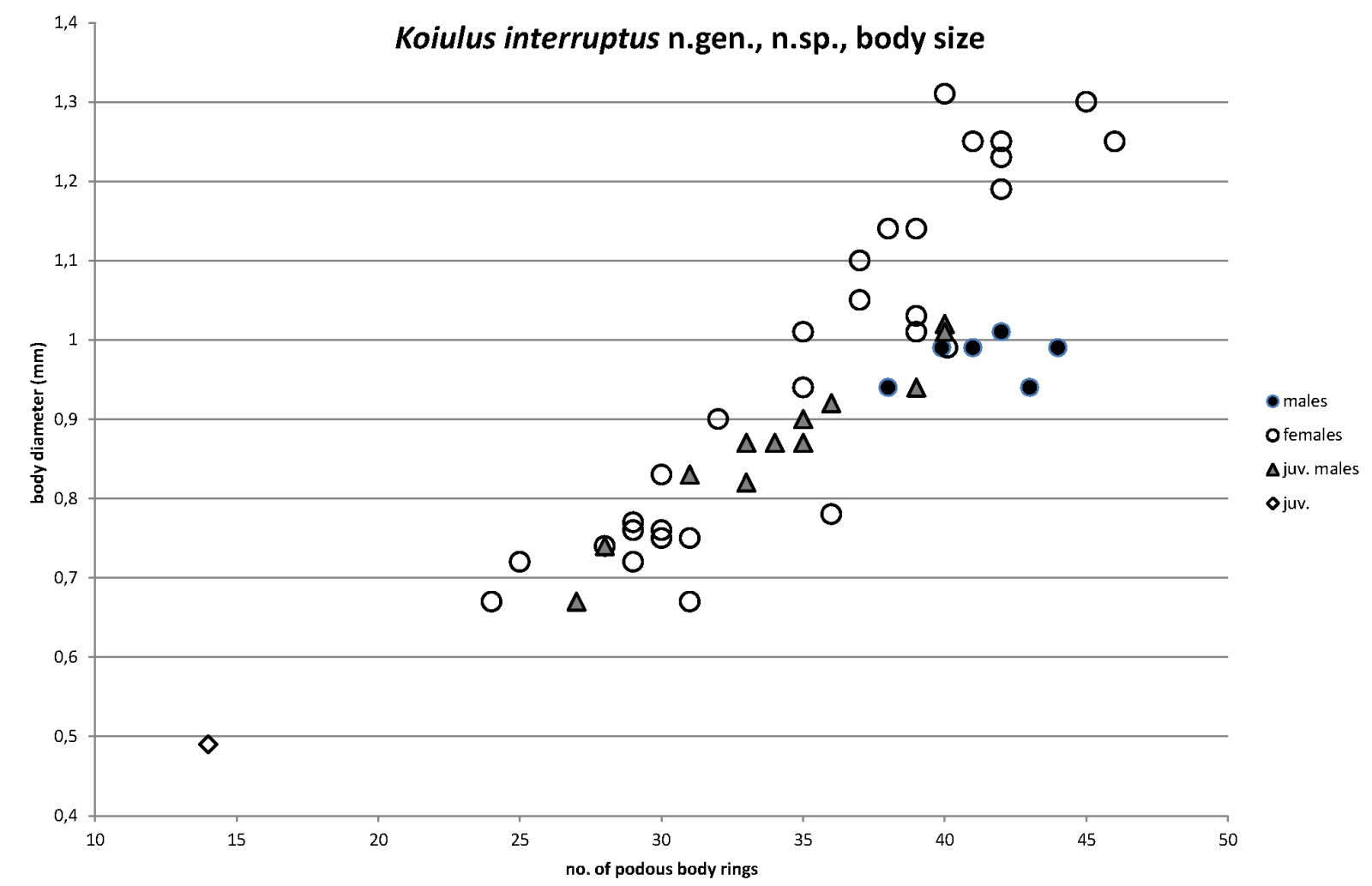

Fig. 2. Koiulus interruptus gen. et sp. nov. Body size as expressed by number of podous body rings and midbody diameter. 

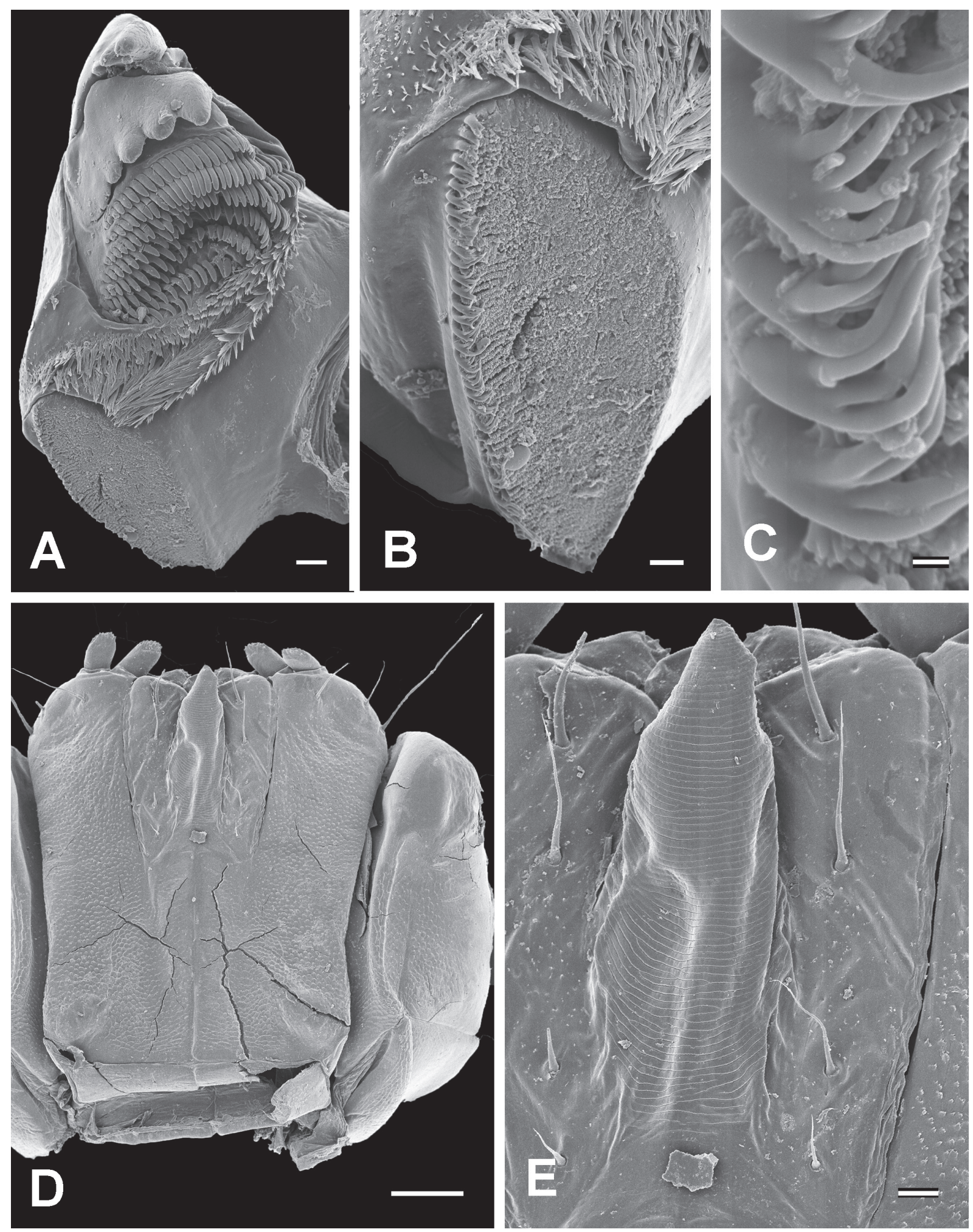

Fig. 3. Koiulus interruptus gen. et sp. nov., paratype, ${ }^{\lambda}$, from the upper course of the river Ko. A. Left mandible. B. Molar plate of left mandible. C. Handlike processes on anterior margin of molar plate. D. Gnathochilarium. E. Lamellae linguales and modified promentum of gnathochilarium. Scale bars: A, $\mathrm{E}=0.02 \mathrm{~mm} ; \mathrm{B}=0.01 \mathrm{~mm} ; \mathrm{C}=0.001 \mathrm{~mm} ; \mathrm{D}=0.1 \mathrm{~mm}$. 
Collum (Fig. 4B). Smooth, with one or two striae along lower margin.

Body RINGS (Figs 1, 4A-D). Slightly vaulted, prozonites smooth, metazonites with longitudinal striae in ventral half. A row of short setae on posterior margin, length of setae ca $0.1 \times$ body diameter. Ozopores present from ring 6 onward, but missing from rings 7, 11, 14 or 15, one of rings 17-20 and several single rings further backward (Fig. 4C).

Telson (Figs 1, 4A). Preanal ring with a short dorsal process and setae along posterior margin. Anal valves each with two setae. Subanal scale with two setae.

Legs (Figs 1, 4A-C). Moderately long and slender. Claws long, weakly curved, without modifications.

\section{Male sexual characters}

MANDiBLEs (Fig. 4B). Stipes with a small, protruding, ventro-posterior lobe.

Gnathochilarium (Fig. 3D-E). Promentum swollen, transversely microstriate, anteriorly produced in triangular tip overreaching lamellae linguales.

First PAIR OF Legs (Figs 4A-B, 5A-C). Strongly enlarged, consisting of an unpaired coxosternum and five-segmented telopodites. Interpretation of basal sclerite as a coxosternum supported by narrow 'trochanters' (not visible on Fig. 5) situated between unpaired sclerite and each of the telopodites. Third telopodomere longer than the others: $3>4>1>2>5$. Telopodomore 1 (prefemur?) massive, ca as broad as long, with an area densely covered in short bristles on anterior side (obscured by a secretion-like substance on imaged specimen). Telopodomere 2 (femur?) much broader than long, with a hump on anterior surface, i.e., in inner curvature of telopodite. Telopodomere 3 (postfemur, or postfemur + tibia?) much longer than any of the others, its basal ca $40 \%$ flattened, much more slender than distal ca $60 \%$. Telopodomere 4 (tibia, tarsus, or tibia+tarsus?) flattened, of uniform width throughout. Telopodomere 5 (strongly reduced tarsus or claw?) very small, hemisphaerical. Telopodomeres $1-4$ with scattered setae, 5 entirely smooth.

SECOND PAIR OF Legs (Fig. 5D-F). Strongly reduced, consisting of an unpaired (coxo?)sternum and threesegmented telopodites. Telopodomere 1 cylindrical, gently curved, ca 3 times as long as broad, with scaly microsculpture on posterior surface and a long disto-mesal seta on anterior surface. Telopodomere 2 barrel-shaped, slightly longer than broad, with a long disto-mesal seta on anterior surface and several shorter, scattered setae. Telopodomere 3 contrastingly black, tapering to narrow tip, here with a bunch of ca 7-8 stout setae with irregularly multi-spiked tips (Fig. 5F); several normal setae scattered over telopodomere surface.

PENIS (Fig. 5D-E). Unpaired, cylindrical, longer than second legs, gradually narrowing towards end or with a slender, parallel-sided tip.

SeVEnth paIR of Legs (Figs 5G-I, 6). Strongly reduced, each leg consisting of three-four podomeres of uncertain homology. Podomere 1 almost twice as long as podomere 2; podomere 1, sometimes also podomeres 2 and 3, with scaly microsculpture on mesal surface and a long (disto-)mesal seta, podomere 2 further with a few short setae. Podomere 3 contrastingly black, pear-shaped or conical, smooth or with a few short setae, sometimes surmounted by a tiny podomere 4 carrying 5 strong setae laterally and a claw apically (Fig. 6).

Seventh Pleurotergite (Fig. 4B-C). With triangular-rounded ventral lobes (protecting gonopods). 


\section{ENGHOFF H. et al., A new genus of mongoliulid millipedes from the Far East of Russia}
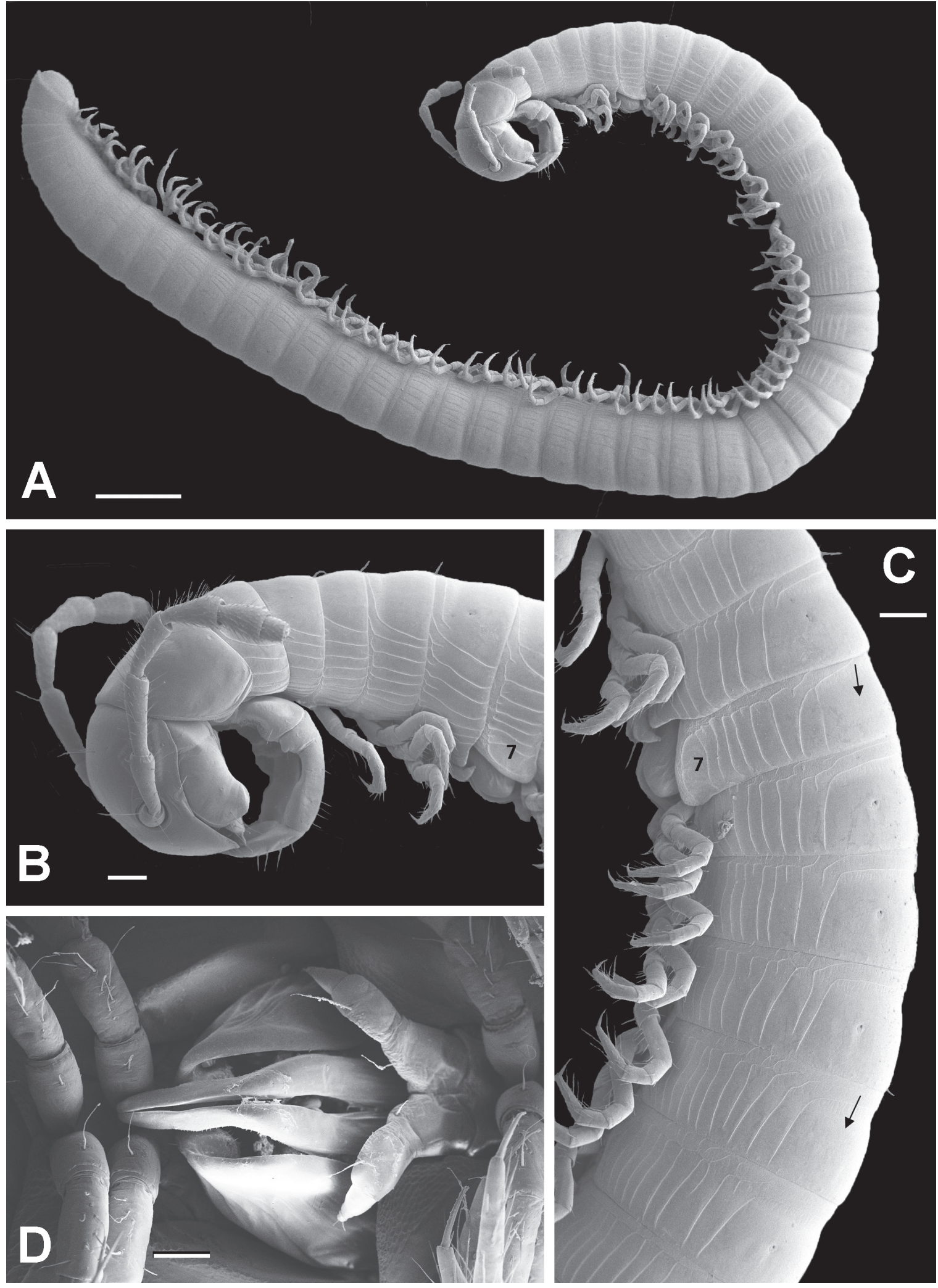

Fig. 4. Koiulus interruptus gen. et sp. nov., paratype, ô, from the upper course of the river Ko. A. Entire body, 39 podous +3 apodous body rings + telson. B. Anterior end. C. Body rings (5)6-12(13); note absence of ozopores on rings 7 and 11 (arrows). D. Leg-pair 7 and gonopods in situ. $7=$ seventh body ring with ventral lobes. Scale bars: $A=1 \mathrm{~mm}$; $-\mathrm{C}=0.2 \mathrm{~mm}$; $\mathrm{D}=0.1 \mathrm{~mm}$. 

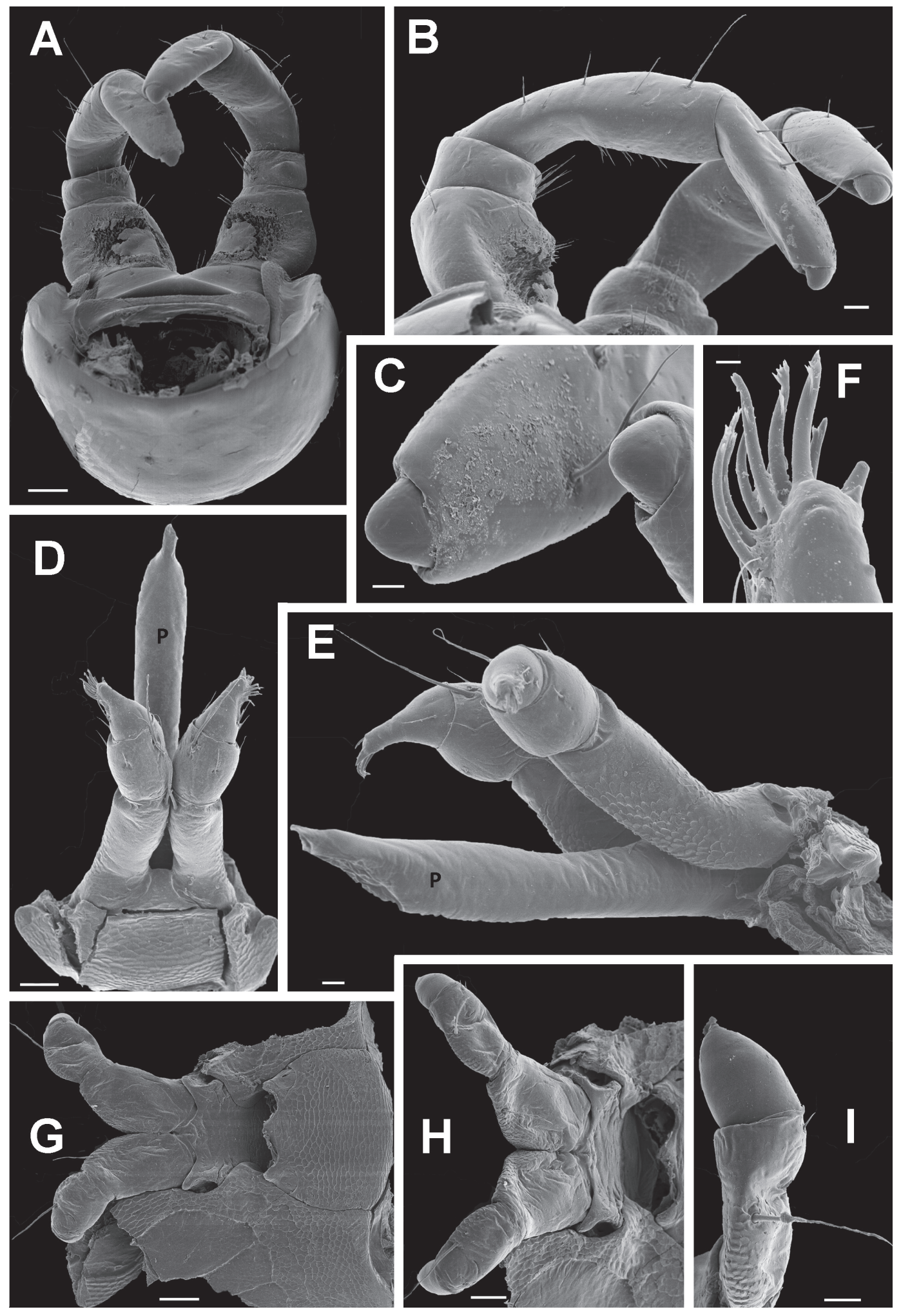

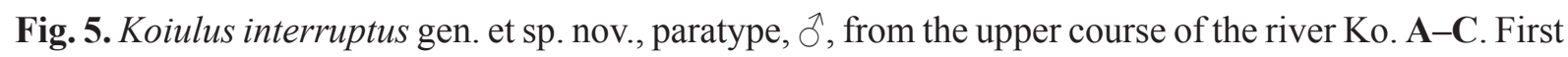
pair of legs. A. Anterior view. B. Sublateral view. C. Tips. - D-F. Second pair of legs, and penis. D. Anterior view. E. Lateral view. F. Modified setae on tip of leg. - G-I. Seventh pair of legs. G. Ventral view. H. Posterior-ventral view. I. Tip of one telopodite. $\mathrm{P}=$ penis. Scale bars: A, G = $0.1 \mathrm{~mm}$; B, D, H = $0.05 \mathrm{~mm} ; \mathrm{C}, \mathrm{E}, \mathrm{I}=0.02 \mathrm{~mm} ; \mathrm{F}=0.005 \mathrm{~mm}$. 
ANTERIOR GONOPODS (Fig. 7). Coxal processes (CX) separate, long and slender, slightly curved posteriad, laterally excavated for accommodation of telopodites, tips rounded. Flagella (FL) strongly reduced, short, finger-like, projecting perpendicularly from coxal process, with strong scaly microsculpture. Telopodite (TLP) almost as long as coxal process, apically with large mesal lobe; tip of lobe with scaly microsculpture and a group of ca 6 short setae. Remaining surface of telopodite smooth, except for some tiny $(\sim 10 \mu \mathrm{m})$ sub-circular, densely porose structures (PS, Fig. 7C-D).

Posterior GONOPODS (Fig. 8). Each posterior gonopod divided from the basis into two equally long branches. Anterior branch (AB) slender, almost parallel-sided, mesally excavated, apical $1 / 3$ with dense cover of retrorse mico-spicules; tip slender, curved up in densely microspiculate spiral. Posterior branch (PB) broad at base, tapering regularly towards tip and hence with a triangular outline; anterior surface excavated for accommodation of anterior branch; an anterior-lateral row of ca 15 short setae; mesal margin distally with subtriangular, anteriad lobes.

\section{Female sexual characters}

Vulva (Fig. 9). Placed vertically in short vulval sacs behind unmodified second leg-pair, very slender, oblong pyriform. Operculum (OP) slightly longer than bursa, with two parallel rows of short setae on anterior surface and several strong setae on distal half; tip subtriangular. Bursa (BU) consisting of a single sclerite, but with longitudinal sutures in basal $3 / 4$ of mesal and lateral sides; four longitudinal rows of setae, one on each side of the two longitudinal sutures. Posterior surface apically divided into two rounded lobes.

A tiny $(\sim 15 \mu \mathrm{m})$ structure of unknown identity was observed next to one of the apical bursal setae (Fig. 9D (arrow)-E). It is sausage-shaped, has an apical pore and is apparent attached by its basal end to the surface of the bursa as well as laterally attached to the neighbouring seta.

\section{Discussion}

\section{Comparison of Koiulus gen. nov. with other Mongoliulidae}

The Mongoliulidae is a small family of julidan millipedes, geographically confined to East Asia (Russian Far East, Korea, China, Japan). The family is closely related to the mainly North American family Parajulidae; the sister-group relationship between the two families is supported by morphological characters (enlarged first male legs, enlarged and soft male promentum; Enghoff 1981) and Kopidoiulus continentalis (Mongoliulidae) comes out as sister group to Uroblaniulus caroliniensis Causey, 1953 (Parajulidae) in the molecular phylogenies of Enghoff et al. (2011, 2013). According to Enghoff et al.
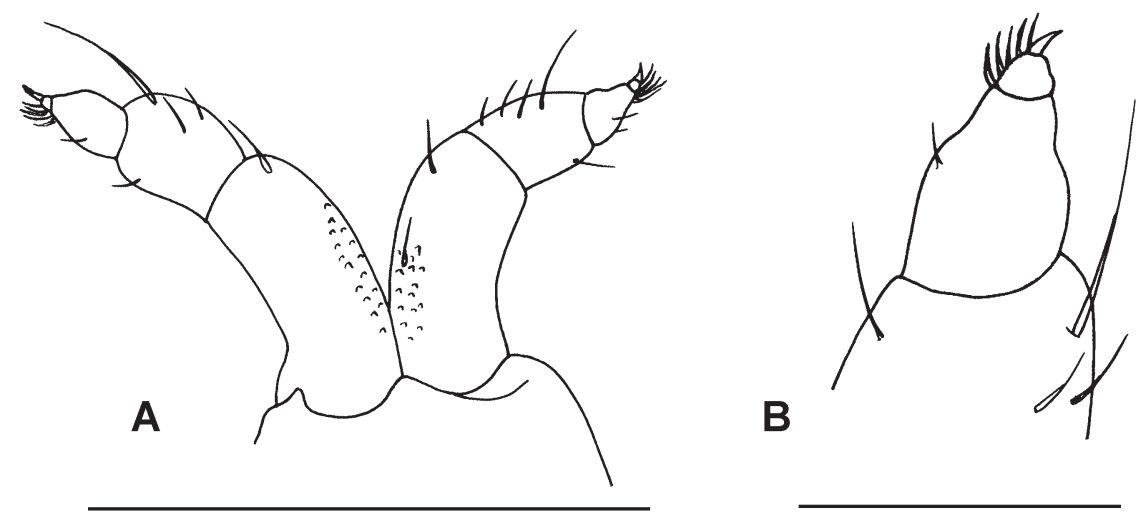

Fig. 6. Koiulus interruptus gen. et sp. nov., paratype, $\hat{\sigma}$, from the environs of the village of Zolotoi, seventh pair of legs. A. Ventral view. B. Tip of the telopodite. Scale bars: A $=0.5 \mathrm{~mm}$; $=0.1 \mathrm{~mm}$. 
(2015) Mongoliulidae differ from Parajulidae by having the claw of the first male legs absent or reduced, the second pair of male legs at most moderately modified, the penis unpaired, the seventh pair of male legs with enlarged coxae and modified and/or size-reduced telopodites (exception: Ussuriiulus), and the anterior gonopods mostly with flagella (reduced to tiny flaps in Kopidoiulus, missing in Ussuriiulus and (?) Ikahoiulus).

Additional distinguishing characters of Mongoliulidae are: Eyes present or absent. Surface of metazonites clearly striate only below ozopore level. The first pair of male legs enlarged (exception: Ansiulus deminutus Mikhaljova, 2001) and modified to a varying degree. The second pair of male legs
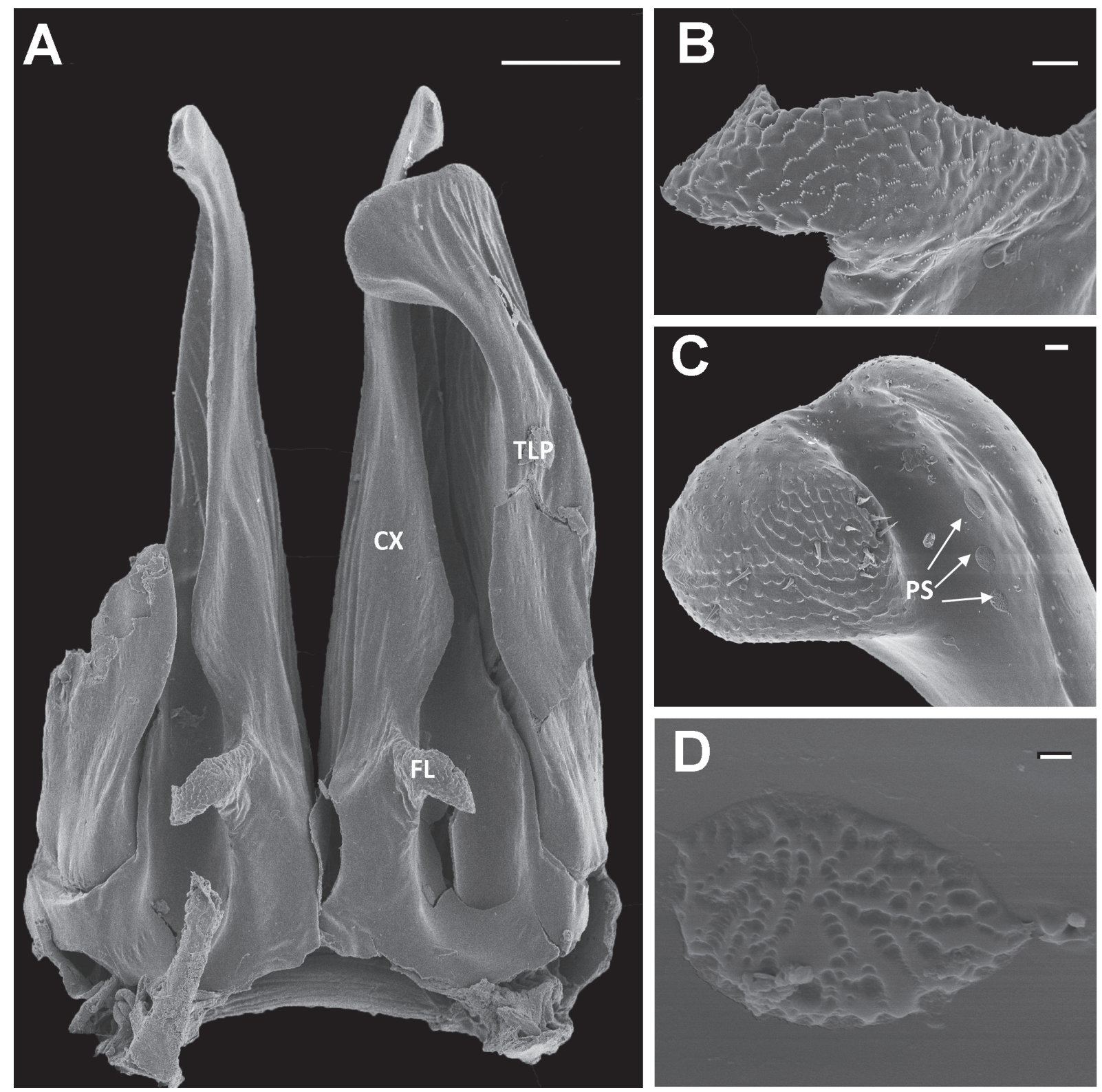

Fig. 7. Koiulus interruptus gen. et sp. nov., paratype, $\widehat{\partial}$, from the upper course of the river Ko, anterior gonopods. A. Posterior view. B. Modified flagellum. C. Tip of left telopodite. D. Porose structure from telopodite. Abbreviations: $\mathrm{CX}=$ coxal process; $\mathrm{FL}=$ flagellum; $\mathrm{PS}=$ porose structure; $\mathrm{TLP}=$ telopodite. Scale bars: $\mathrm{A}=0.1 \mathrm{~mm} ; \mathrm{B}-\mathrm{C}=0.01 \mathrm{~mm} ; \mathrm{D}=0.001 \mathrm{~mm}$. 

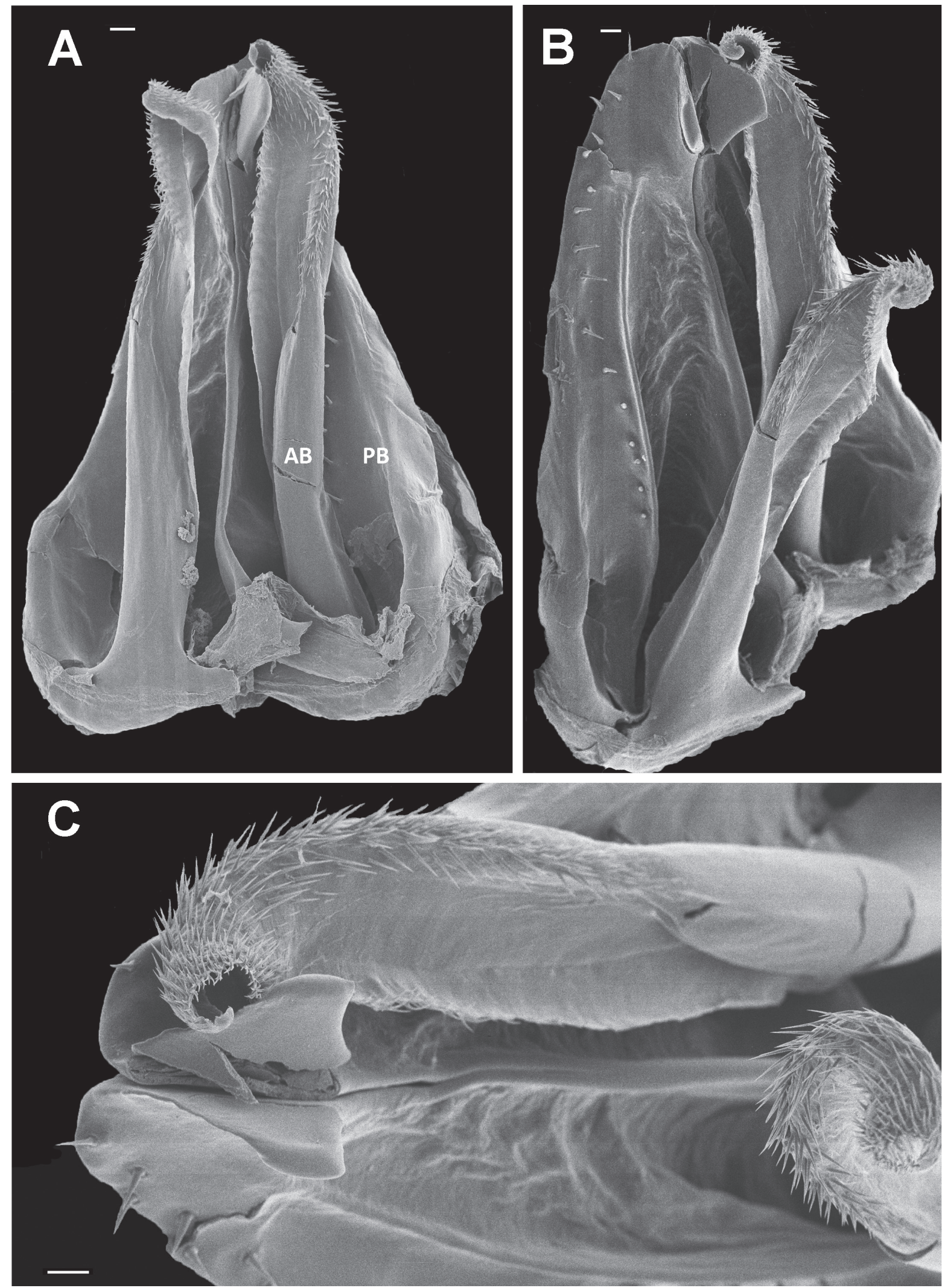

Fig. 8. Koiulus interruptus gen. et sp. nov., paratype, $\widehat{\partial}$, from the upper course of the river Ko, posterior gonopods. A. Anterior view. B. Posterior-lateral view. C. Posterior-apical view. Abbreviations: $\mathrm{AB}=$ anterior branch; $\mathrm{PB}=$ posterior branch. Scale bars $=0.02 \mathrm{~mm}$. 

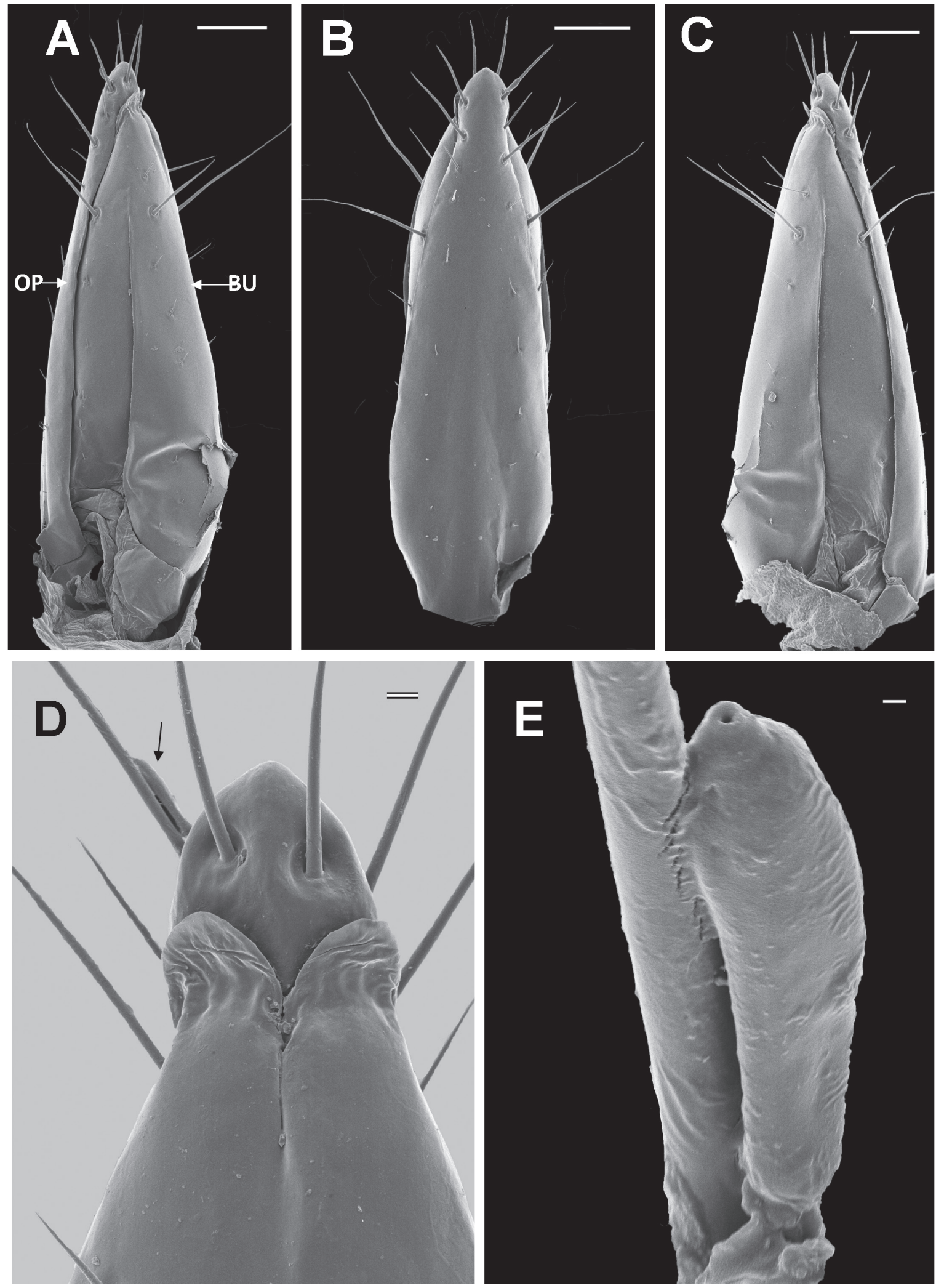

Fig. 9. Koiulus interruptus gen. et sp. nov., paratype,, , from upper course of river Ko, right vulva. A. Lateral view. B. Anterior view. C. Mesal view. D. Tip, posterior view; arrow points to unknown structure. E. Unknown structure from opercular seta. Abbreviations: $\mathrm{BU}=$ bursa; $\mathrm{OP}=$ operculum. Scale bars: $A-C=0.1 \mathrm{~mm} ; \mathrm{D}=0.01 \mathrm{~mm} ; \mathrm{E}=0.001 \mathrm{~mm}$. 
ENGHOFF H. et al., A new genus of mongoliulid millipedes from the Far East of Russia

normal (exception: Koiulus gen. nov.), somewhat reduced in size, coxae prolonged. Anterior gonopods with coxal processes, flagella and reduced telopodites. Posterior gonopod with or without telopodites.

Koiulus gen. nov. shares all the diagnostic characters of Mongoliulidae including the reduced claw of the first pair of legs, the unpaired penis, the modified seventh male legs and possibly also the presence of flagella, although these seem to be strongly modified.

Table 1 shows a comparison of Koiulus gen. nov. with the seven already described genera of Mongoliulidae.

The new genus seems to be especially similar to the genera known from the Far East of Russia, Ansiulus, Skleroprotopus, Kopidoiulus and Ussuriiulus, in the structure of the male gnathochilarial promentum, the first and seventh pairs of male legs (however, the latter is unmodified in Ussuriiulus), separate coxal processes and the relatively long telopodites of the anterior gonopod. With Kopidoiulus, Ikahoiulus and Ussuriiulus it shares the reduced to absent flagella, and with Ussuriiulus it shares the peculiar lack of ozopores on certain body rings, a condition unknown in all other juliformian millipedes. (In the original description of Uenoiulus notabilis Murakami, 1971, there is a drawing of the anterior end of the holotype male in which the ozopore seems to be missing from body ring 7 . We have examined four male and two female paratypes of $U$. notabilis and have found that ozopores are present in a continuous series starting from ring 6 , but in males, where ring 7 is very narrow, the pore is difficult to see.)

On the other hand, the new genus stands out by the strongly modified second pair of male legs.

Species of Ansiulus, Skleroprotopus and Kopidoiulus appear to be morphologically rather variable (Mikhaljova 1997; Mikhaljova \& Korsós 2003). The male leg-pair 7 and the gonopods are most often subject to variability. As regards the male leg-pair 7, the number of segments of the telopodite is particularly unstable and variability may even occur between both sides of the same specimen (Mikhaljova \& Korsós 2003). In Koiulus interruptus gen. et sp. nov. the number of segments of male leg 7 ranges from 3 in the males from the upper course of River Ko to 4 in the male from the environs of Zolotoi village.

The close resemblance, including gonopodal characters, between Ansiulus and Skleroprotopus, in combination with the high variability in some species, might be evidence for the synonymy of these genera. The same applies to Kopidoiulus andIkahoiulus. This will be discussed in a separate article (Mikhaljova in prep.).

\section{Postembryonic development}

Fig. 2 clearly shows that males are thinner than females with similar numbers of podous rings. Interestingly, smaller juvenile males seem to follow the same "growth-pattern", expressed as "diameter per podous ring" as females, whereas adult males, as well as larger juvenile males, are thinner than females, the difference increasing with increasing numbers of podous rings. It thus seems that the development of a more slender body in adult males is coupled to the onset of maturity. This tendency was also observed in the genus Cylindroiulus Verhoeff, 1894, family Julidae by Enghoff (1982).

The implications of the missing defence glands for interpretation of postembryonic growth will be discussed in a separate article.

\section{Acknowledgements}

We are most grateful to Dr Alexey Solodovnikov, Aslak Kappel Hansen and Matthias Justesen who kindly collected millipedes during their expedition to the Russian Far East, as well as to Dr Gennady Ganin (Khabarovsk, Russia) who collected some additional material, to Dr Hirotugo Ono, NMNS, who 


\begin{tabular}{|c|c|c|c|c|c|c|c|c|}
\hline 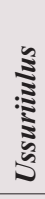 & 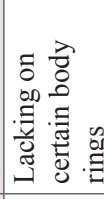 & 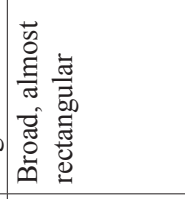 & 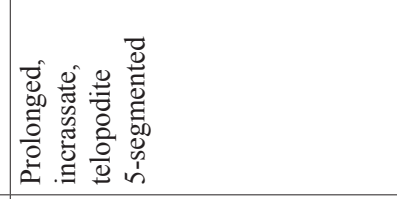 & 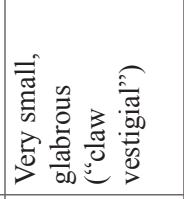 & 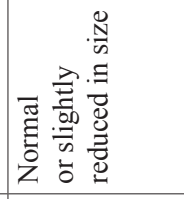 & 芩 & 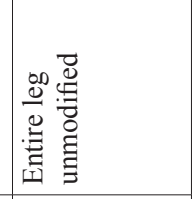 & 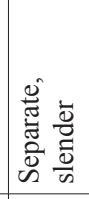 \\
\hline 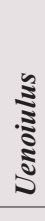 & 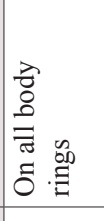 & 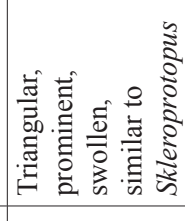 & 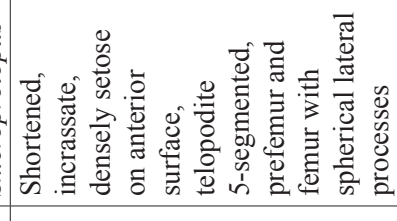 & 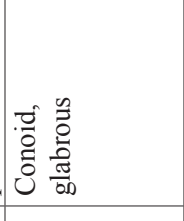 & 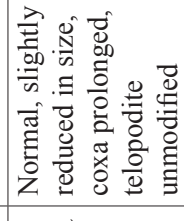 & $\frac{0}{z}$ & 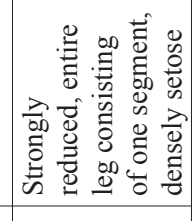 & 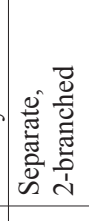 \\
\hline है & 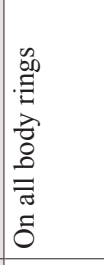 & 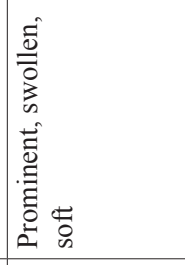 & 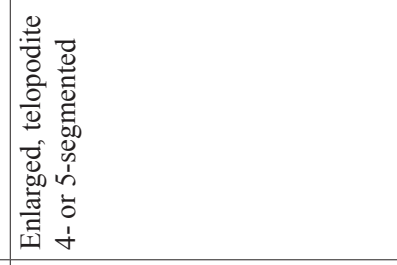 & 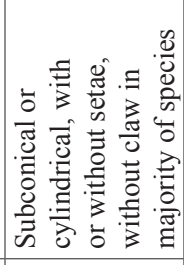 & 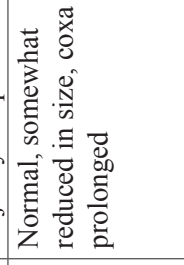 & 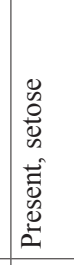 & 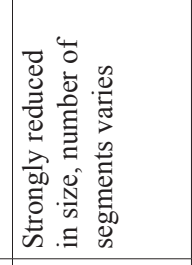 & 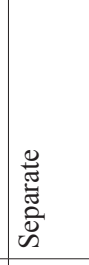 \\
\hline 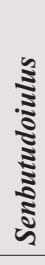 & 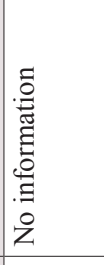 & $\begin{array}{l}\bar{\sigma} \\
0 \\
00 \\
00 \\
\tilde{0} \\
0 \\
0\end{array}$ & 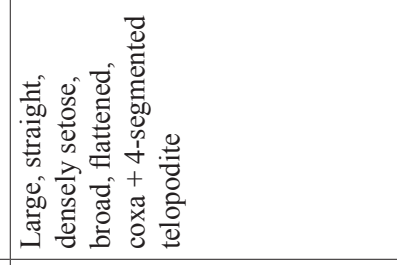 & 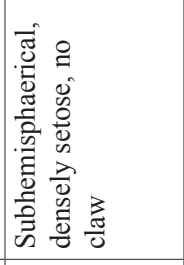 & 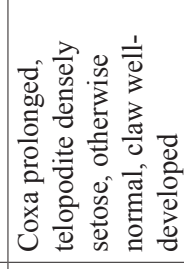 & 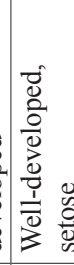 & 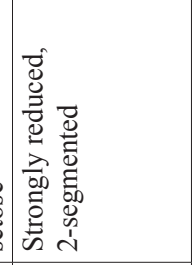 & 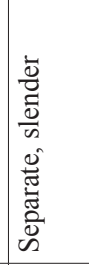 \\
\hline 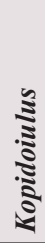 & 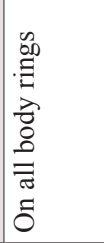 & 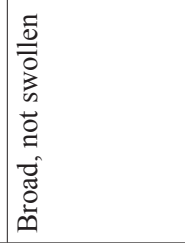 & 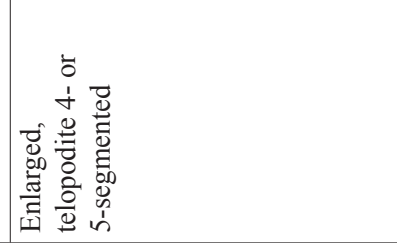 & 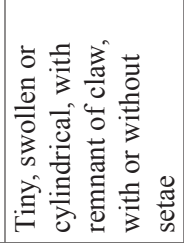 & 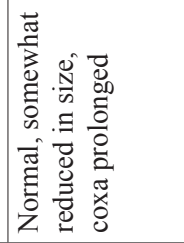 & 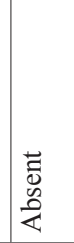 & 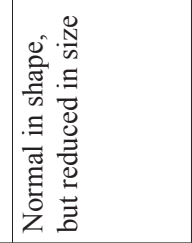 & 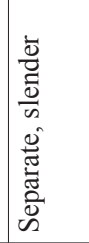 \\
\hline 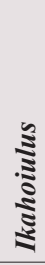 & 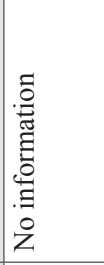 & 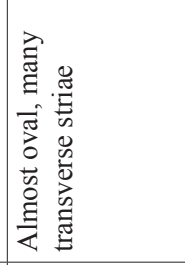 & 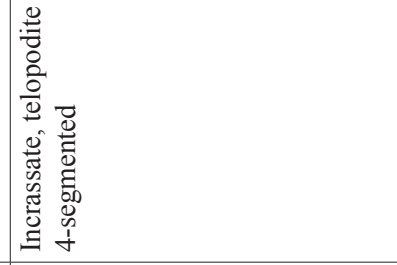 & 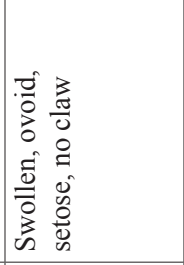 & 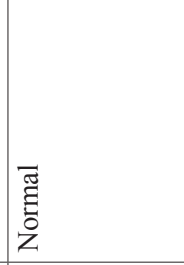 & 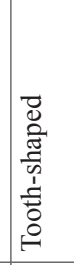 & 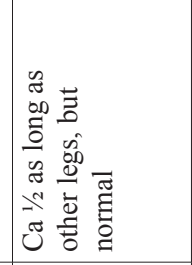 & 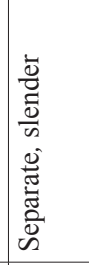 \\
\hline 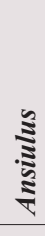 & 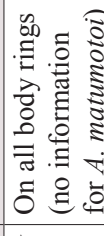 & 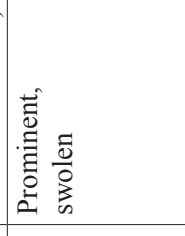 & 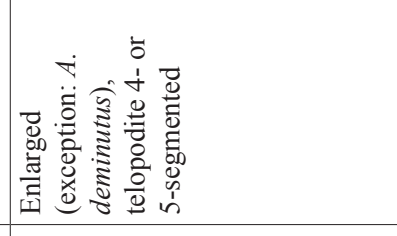 & 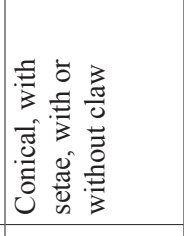 & 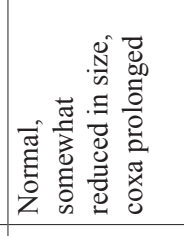 & 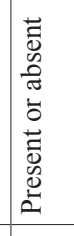 & 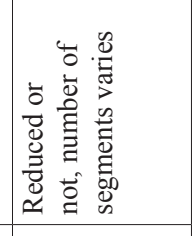 & 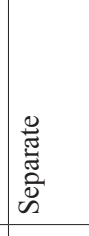 \\
\hline 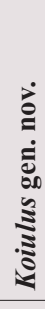 & 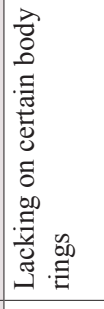 & 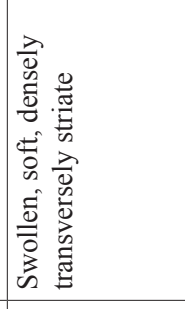 & 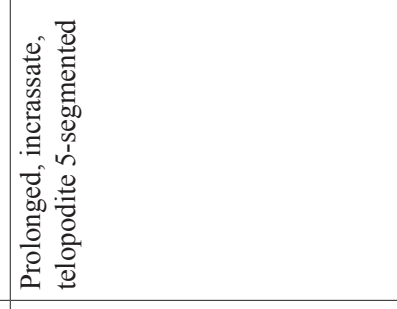 & 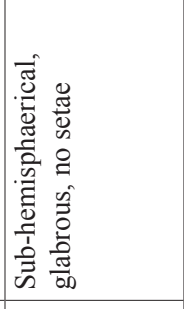 & 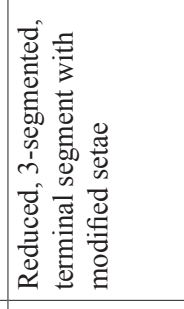 & 气̆ & 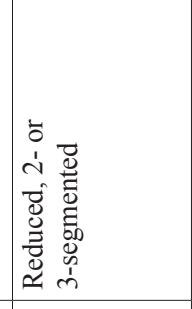 & 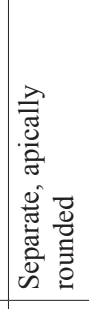 \\
\hline & 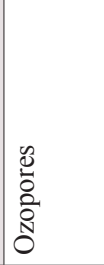 & 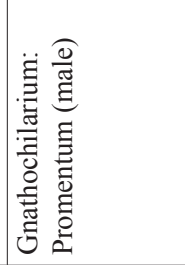 & 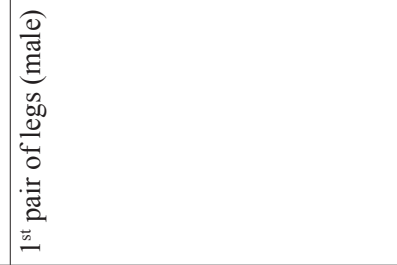 & 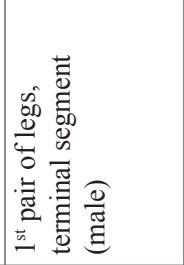 & 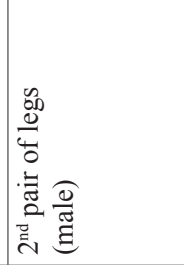 & 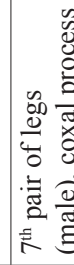 & 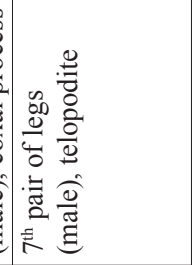 & 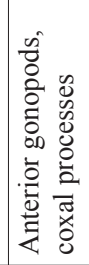 \\
\hline
\end{tabular}




\begin{tabular}{|c|c|c|c|c|c|}
\hline 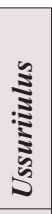 & 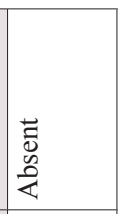 & 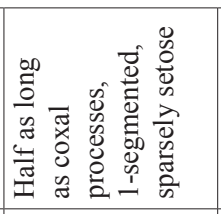 & 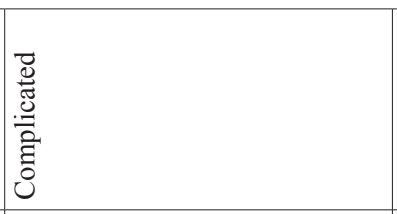 & 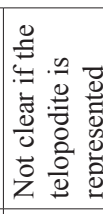 & 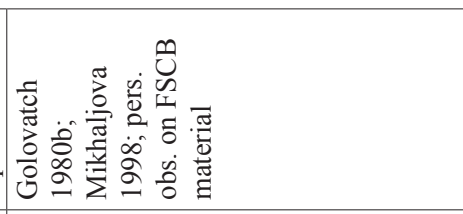 \\
\hline 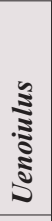 & 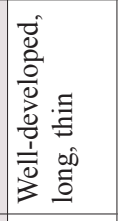 & 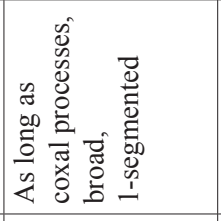 & 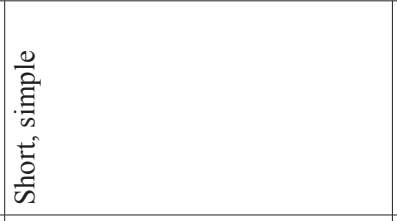 & 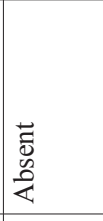 & 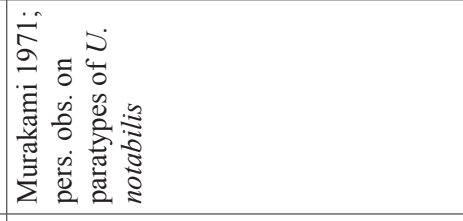 \\
\hline & 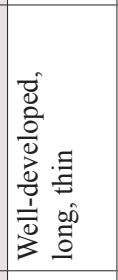 & 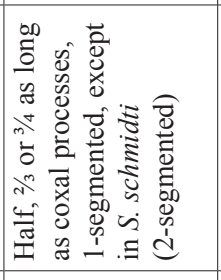 & 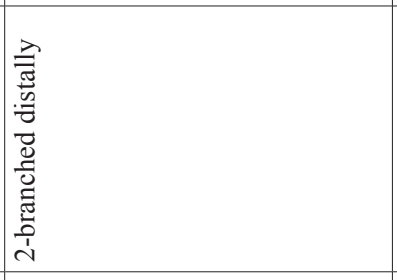 & $\begin{array}{l}\overrightarrow{0} \\
0 \\
0 \\
\text { \& }\end{array}$ & 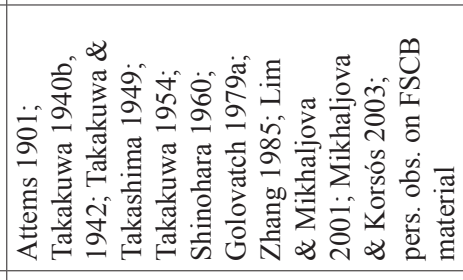 \\
\hline & 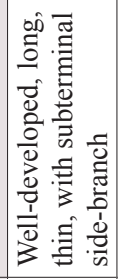 & 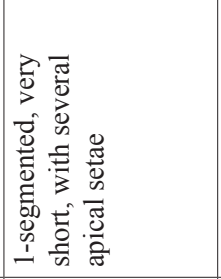 & 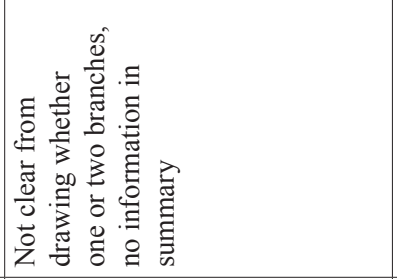 & $\begin{array}{l}\vec{z} \\
\overline{0} \\
\text { 峞 }\end{array}$ & 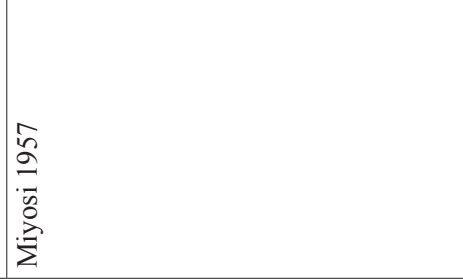 \\
\hline ב⿱艹 & 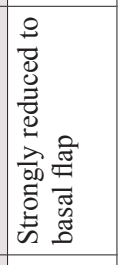 & 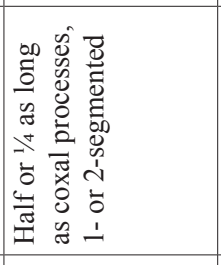 & 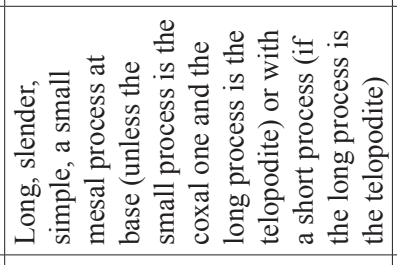 & 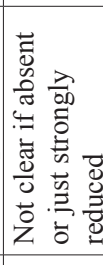 & 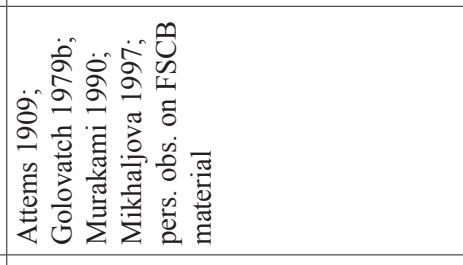 \\
\hline 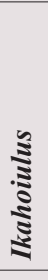 & 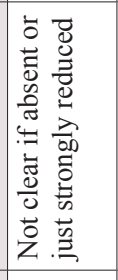 & 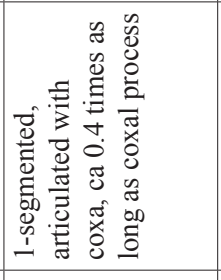 & 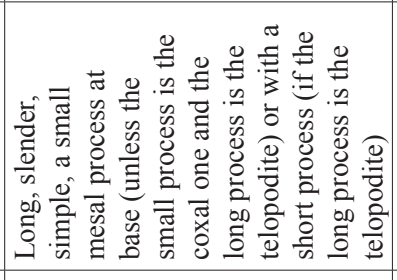 & 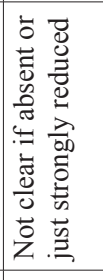 & 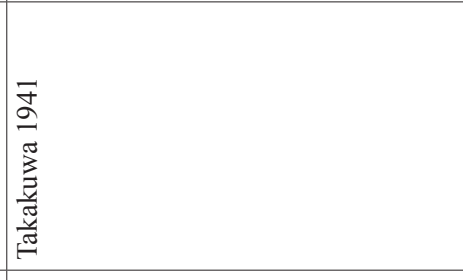 \\
\hline 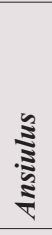 & 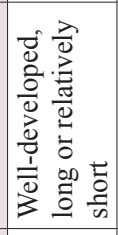 & 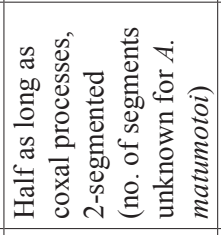 & 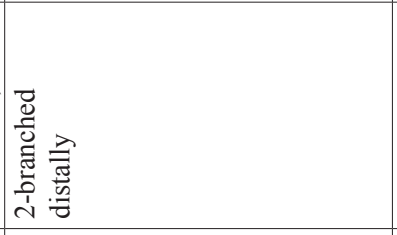 & 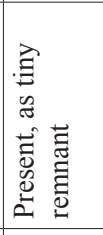 & 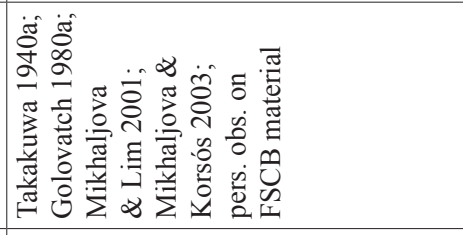 \\
\hline 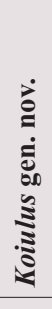 & 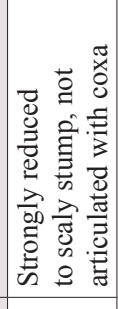 & 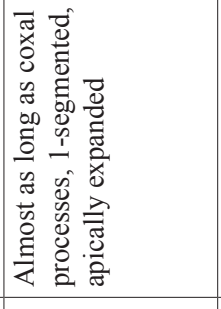 & 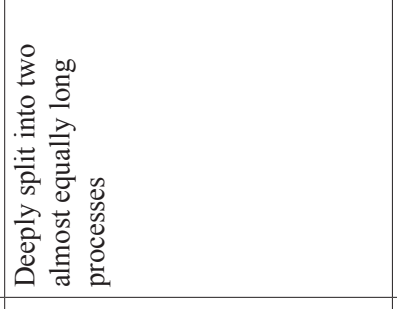 & $\begin{array}{l}\vec{z} \\
\overrightarrow{0} \\
\text { \& } \\
\end{array}$ & 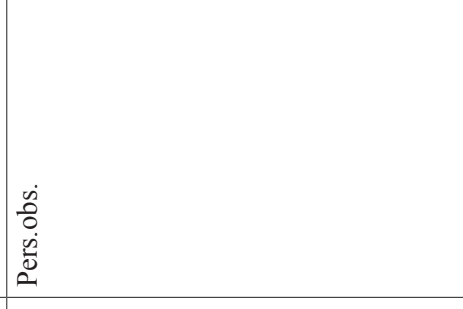 \\
\hline & 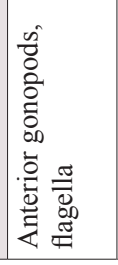 & 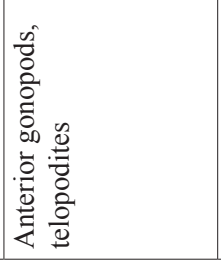 & 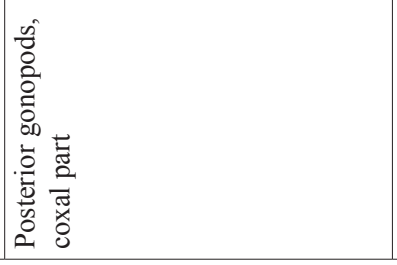 & 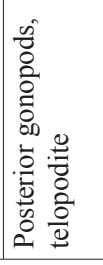 & 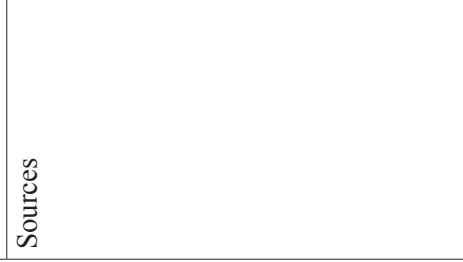 \\
\hline
\end{tabular}


kindly arranged a loan of Uenoiulus notabilis paratypes, to Anders Illum who assisted with photography and scanning electron micrography, to Mrs Galina Sinelnikova (Vladivostok, Russia) who kindly inked Fig. 6, and to Dragan Antić and Sergei Golovatch for careful reviews of the manuscript.

\section{References}

Attems C. 1901. Myriopoden. In: Horváth G. (ed.) Zoologische Ergebnisse der dritten asiatischen Forschungsreise des Grafen Zichy 2: 275-310. Hornyánszky, Budapest; Hiersemann, Leipzig.

Attems C. 1909. Die Myriopoden der Vega-Expedition. Arkiv för Zoologi 5 (3): 1-84.

Enghoff H. 1981. A cladistic analysis and classification of the millipede order Julida. Zeitschrift für zoologische Systematik und Evolutionsforschung 19: 285-319.

Enghoff H. 1982. The millipede genus Cylindroiulus on Madeira - an insular species swarm (Diplopoda, Julida: Julidae). Entomologica Scandinavica, Supplement 18: 1-142.

Enghoff H., Petersen G. \& Seberg O. 2011. Phylogenetic relationships in the millipede family Julidae. Cladistics 27: 606-616. https://doi.org/10.1111/j.1096-0031.2011.00360.x

Enghoff H., Petersen G. \& Seberg O. 2013. The aberrant millipede genus Pteridoiulus and its position in a revised molecular phylogeny of the family Julidae (Diplopoda, Julida). Invertebrate Systematics 27: 515-529. https://doi.org/10.1071/IS13016

Enghoff H., Golovatch S., Short M., Stoev P. \& Wesener T. 2015. Diplopoda - Taxonomic overview. In: Minelli A. (ed.) The Myriapoda 2. Treatise on Zoology - Anatomy, Taxonomy, Biology: 363-453. Brill, Leiden, Boston.

Golovatch S.I. 1979a. A new genus of the superfamily Parajuloidea (Diplopoda) new to the USSR. Entomologicheskoe Obozrenie 58 (4): 904-908 [in Russian, English summary].

Golovatch S.I. 1979b. Three new to the USSR fauna genera of Diplopoda-Chilognatha. Zoologicheski Zhurnal 58 (3): 336-343 [in Russian, English summary].

Golovatch S.I. 1980a. A contribution to the millipede fauna of Korea (Diplopoda). Folia Entomologica Hungarica 41 (1): 49-58.

Golovatch S.I. 1980b. New forms of Diplopoda from the Soviet Far East and their zoogeographical relationships. Zoologicheski Zhurnal 59 (2): 199-207 [in Russian, English summary].

Hoffman R.L. \& Howell K.M. 1983. Dendrostreptus, a new genus for an arboreal Tanzanian milliped, with notes on related forms. Revue de Zoologie africaine 97 (3): 625-632.

Hoffman R.L. \& Howell K.M. 1995. On the status of Microtrullius Attems, 1950, an enigmatic genus of the diplopod family Spirostreptidae. Journal of African Zoology 109: 173-184.

Hoffman R.L. \& Howell K.M. 1996. Synopsis of Macrolenostreptini, a new tribe of Tanzanian spirostreptid millipeds (Diplopoda Spirostreptida). Tropical Zoology 9: 441-453. https://doi.org/10.108 $\underline{0 / 03946975.1996 .10539322}$

Lim K.Y. \& Mikhaljova E.V. 2001. A new species of the millipede genus Skleroprotopus Attems, 1901 (Diplopoda: Julida: Mongoliulidae) from Korea. Arthropoda Selecta 9 (2): 119-122.

Mikhaljova E.V. 1997. Review of the cavernicolous millipede fauna of the Far East of Russia, with description of a new troglophilic species (Diplopoda). Arthropoda Selecta 5 (3-4): 143-149.

Mikhaljova E.V. 1998. The millipedes of the Far East of Russia (Diplopoda). Arthropoda Selecta 7 (1): 1-77.

Mikhaljova E.V. \& Korsós Z. 2003. Millipedes (Diplopoda) from Korea, the Russian Far East, and China in the collection of the Hungarian Natural History Museum. Acta Zoologica Scientiarum Hungaricae 49 (3): $215-242$. 
ENGHOFF H. et al., A new genus of mongoliulid millipedes from the Far East of Russia

Mikhaljova E.V. \& Lim K.Y. 2001. New millipedes from Korea, with notes on identity of Epanerchodus koreanus Verhoeff, 1937 (Diplopoda). Arthropoda Selecta 10 (1): 19-26.

Miyosi Y. 1957. Beiträge zur Kenntnis japanischer Myriopoden. 19. Aufsatz: Über eine neue Gattung und zwei neue Arten von Diplopoden. Dobutsugako Zasshi [The Zoological Magazine] 66: 29-33 [in Japanese, German summary].

Murakami Y. 1971. The fauna of the insular lava caves in West Japan. X. Myriapoda. Bulletin of the National Science Museum, Tokyo 14 (3): 311-332.

Murakami Y. 1990. The millipeds of the genus Kopidoiulus (Diplopoda, Julida, Mongoliulidae). Journal of the Speleological Society of Japan 15: 1-14.

Shinohara K. 1960. Three new species of Juloidea (Diplopoda) from Chichibu. Bulletin of the Chichibu Museum of Natural History 10: 23-30 [in Japanese, English summary].

Takakuwa Y. 1940a. Über eine neue Diplopodengattung aus Japan. Transactions of the Sapporo Natural History Society 16 (3): 117-119.

Takakuwa Y. 1940b. Über Scleroprotopus-Arten (Chilopoda) [sic]. Annotationes Zoologicae Japonenses 19 (1): 19-22.

Takakuwa Y. 1941. Eine neue Gattung der Paraiulidae (Diplopoda). Zoological Magazine, Tokyo 53: 364-366.

Takakuwa Y. 1942. Zur Kenntnis der japanischen Diplopoden. Annotationes Zoologicae Japonenses 21 (1): 39-47.

Takakuwa Y. 1954. Diplopoden aus Japan und ihm angrenzenden Gebieten. Japan Society for the Promotion of Science, Tokyo. [in Japanese].

Takakuwa Y. \& Takashima H. 1949. Myriapods collected in Shansi, North China. Acta Arachnologica 11 (3-4): 51-69 [in Japanese, English summary].

Zhang C.Z. 1985. A new millipede of the genus Skleroprotopus in Stone Buddha Cave, Fangsheng County, Beijing. In: Karst Geomorphology and Speleology: 154-156. Science Press, Beijing [in Chinese].

Manuscript received: 21 December 2016

Manuscript accepted: 23 January 2017

Published on: 6 June 2017

Topic editor: Rudy Jocqué

Desk editor: Kristiaan Hoedemakers

Printed versions of all papers are also deposited in the libraries of the institutes that are members of the EJT consortium: Muséum national d'Histoire naturelle, Paris, France; Botanic Garden Meise, Belgium; Royal Museum for Central Africa, Tervuren, Belgium; Natural History Museum, London, United Kingdom; Royal Belgian Institute of Natural Sciences, Brussels, Belgium; Natural History Museum of Denmark, Copenhagen, Denmark; Naturalis Biodiversity Center, Leiden, the Netherlands; Museo Nacional de Ciencias Naturales-CSIC, Madrid, Spain; Real Jardín Botánico de Madrid CSIC, Spain. 


\section{Appendix}

\section{Species of Mongoliulidae}

Ansiulus Takakuwa, 1940

A. aberrans Mikhaljova \& Korsós, 2003 (Korea, Russian Far East)

A. deminutus Mikhaljova, 2001 (Korea)

A. legitimus Golovatch, 1980 (Korea)

A. matumotoi Takakuwa, 1940 (Korea)

Ikahoiulus Takakuwa, 1941

I. leucosoma Takakuwa, 1941 (Japan)

Koiulus gen. nov.

$K$. interruptus gen. et sp. nov. (Russian Far East)

Kopidoiulus Attems, 1909 (overview: Murakami 1990)

K. albulus Haga, 1956 (Japan)

K. caecus Attems, 1909 (Japan)

K. continentalis Golovatch, 1979 (Russian Far East, NE China)

K. khasanicus Mikhaljova, 1997 (Russian Far East)

K. longus Shinohara, 1963 (Japan)

K. ocellatus Takakuwa, 1940 (Japan)

K. truncatus Murakami, 1990 (Japan)

Senbutudoiulus Miyosi, 1957

S. platypodus Miyosi, 1957 (Japan)

Skleroprotopus Attems, 1901

Synonymy

Mongoliulus Pocock, 1903

Paraprotopus Verhoeff, 1939

Nesoprotopus Verhoeff, 1939

S. chichibuensis Shinohara, 1960 (Japan)

S. chollus Mikhaljova \& Korsós, 2003 (Korea)

S. confucius Attems, 1901 (China)

S. coreanus (Pocock, 1895) (Korea, Russian Far East) (syn.: S. simileserratus Golovatch, 1980)

S. costatus Mikhaljova \& Korsós, 2003 (Korea)

S. hakui Takakuwa, 1940 (Korea)

S. ikedai Takakuwa, 1940 (Japan)

S. inferus Verhoeff, 1939 (Japan)

S. insularum Verhoeff, 1939 (Japan)

S. laticoxalis laticoxalis Takakuwa, 1942 (China, North Korea)

S. laticoxalis longus Murakami \& Paik, 1968 (Korea)

S. membranipedalis Zhang, 1985 (China)

S. montanus Takakuwa, 1942 (Japan)

S. okiensis Takakuwa, 1940 (Japan)

S. osedoensis Miyosi, 1957 (Japan)

S. ramuliferus Lim \& Mikhaljova, 2000 (Korea)

S. schmidti Golovatch, 1979 (Russian Far East)

S. serratus Takakuwa \& Takashima, 1949 (China) 
ENGHOFF H. et al., A new genus of mongoliulid millipedes from the Far East of Russia

S. sidegatakedensis Miyosi, 1957 (Japan)

S. simplex Takakuwa, 1940 (Japan)

S. torii Takakuwa, 1940 (Japan)

Uenoiulus Murakami, 1971

U. notabilis Murakami, 1971 (Japan)

Ussuriiulus Golovatch, 1980

U. pilifer Golovatch, 1980 (Russian Far East) 